\title{
Graduates' Employability Skills Based on Current Job Demand through Electronic Advertisement
}

\author{
Nik Hairi Omar ${ }^{1}$, Azmi Abdul Manaf ${ }^{1}$, Rusyda Helma Mohd ${ }^{1}$, Arena Che Kassim ${ }^{1}$ \& Khairani Abd. Aziz ${ }^{1}$ \\ ${ }^{1}$ School of Psychology and Human Development, Faculty of Social Sciences and Humanities, Universiti \\ Kebangsaan Malaysia, Bangi, Malaysia. \\ Correspondence: Nik Hairi Omar, School of Psychology and Human Development, Faculty of Social Sciences \\ and Humanities, Universiti Kebangsaan Malaysia, 43600 UKM Bangi, Selangor, Malaysia. Tel: 60-3-8921-3937. \\ E-mail: hairi@ukm.my
}

Received: June 4, $2012 \quad$ Accepted: June 16, $2012 \quad$ Published: July 16, 2012

doi:10.5539/ass.v8n9p103 URL: http://dx.doi.org/10.5539/ass.v8n9p103

\begin{abstract}
In Malaysia, there is a profusion of evidence of high graduate unemployment since many graduates are found lacking of what are needed to acquire and to maintain their jobs. In this paper, graduate employability skills were analyzed based on four major criteria: qualification, academic score, experience and specific soft skills. The data and information used were extracted from 300 online job advertisements accessed via electronic databases at http://www.JobStreet.com.my from January to March 2011. A simple checklist form was developed to quantify the information from ads into quantitative data that was later keyed in the Statistical Package for Social Science for descriptive analyses. Based on the data, it was concluded that graduates with bachelor degrees were more likely to be employable due to high demand. It was also found that academic excellence based on CGPA was not the utmost factor for graduate employability. However, since less than one-third ads were free from work experiences requirement, fresh graduates only secured a little chance to be recruited. Another factor that limited graduates employability was high demand of specific soft skills requested by employers, among which were graduates with high quality of communication/interpersonal skills, foreign language proficiency, ICT/technical skills, high spirit of teamwork and specific personal attributes. Results concluded that graduate unemployment rate will continue to increase unless the Higher Education Institution (HEI) and the graduates are prepared to sharpen their soft skills according to market niche. It is suggested that the HEI work more closely with industries, professional bodies and society through the establishment of university-industry link cooperation that will become a catalyst for soft skills enhancement.
\end{abstract}

Keywords: employability, graduate, job demand, employer, advertising, industry

\section{Introduction}

Graduate employability is a set of achievements skills, understandings and personal attributes that makes graduates more likely to gain employment and be successful in their chosen occupations, which benefits themselves, the workforce, the community and the economy (Yorke, 2008). They are generally skills that cut horizontally across all industries and vertically across all jobs from entry level to chief executive officer (Sherer and Eadie, 1987; Bunt et al., 2005). From the employers' perspective 'employability' seems to refer to 'work readiness', that is, possession of the skills, knowledge, attitudes and commercial understanding that will enable graduates to make productive contributions to organizational objectives soon after commencing employment (Mason et al., 2006).

Present employers at the national and global economies tend to recruit graduates with high soft skills competencies. As stated by Winterbotham et al. (2001), overall employer are less demanding of academic excellence and technical skills, and considers them trainable if candidates are able to demonstrate positive attributes and soft skills. For many employers, the weaknesses of graduate soft skills are observable prior screening process, interview or selection sessions that is based on candidate physical appearances, aptitudes ability, communication and other personal talents. Such examples are dress code, appearances, conversation, confidence, motivation, flexibility, positive gesture, mannerisms and resourcefulness (Devins and Hogarth, 2005; Newton et al., 2005; Bunt et al., 2005; Taylor, 2005). In United Kingdom, one-fifth of the reported vacancies 
could not be filled due to lack of applicants' soft skills (Learning and Skills Council- LSC, 2003). While in Malaysia, 70 percent graduates are unemployed within 6 months of graduation due to the same reason (Suresh, 2006).

Many scholars argue that graduates leave universities without sufficient soft skills and understanding which are necessary to succeed in the working world (Singh and Singh, 2008; Kamal, 2006; Abdul Rahim, 2000; Mohd Sobri, 1990). In Malaysia, there is a profusion of evidence of high graduate unemployment since many graduates are found lacking of what are needed to acquire and to maintain their jobs. For example, there are 103,171 graduate jobseekers registered in JobMalaysia.com from early of January to 29 March 2009. The number has growth to a total of 385,800 in June 2009 (MOHE, 2009). According to a survey conducted on 3300 human resource personnels and employers by JobStreet.com (a Malaysian employment agency) in 2005, the factors relating to graduate unemployment are various, among them are weak English (56 percent), bad social etiquette (36 percent), demanding too much pay ( 32 percent), irrelevant degrees ( 30 percent), too choosy ( 23 percent) and no vacancies (14 percent). Weak English and bad social etiquette are elements of soft skills on the top reasons for graduates being unemployed. These findings show that Malaysian graduates are unemployed not because they are unintelligent but rather because most of them lack soft-skills (Singh and Singh 2008). General consensus among Malaysian employers indicates that Malaysian graduates are well trained in their areas of specialization but unfortunately they lack the 'soft skills', such as communication, problem solving, interpersonal and the ability to be flexible (Nurita et al., 2004; Suresh, 2006; Mohamad Sattar et al., 2009; Nur Atiqah et al., 2006).

Due to the incapacitation of graduate soft skills, the Higher Education Institution (HEI) has come under intense pressure to equip students with more than just academic skills (Abdul Rahim, 2000). A number of reports issued by employers have urged universities to make more explicit efforts to develop the 'key', 'core', 'transferable', 'soft', 'employable' and/or 'generic skills' needed in many types of employment (Singh and Singh, 2008). This has led the Ministry of Higher Education Malaysia (MOHE) to introduce eight learning outcomes for non-curricular activities at university to nurture employability skills among graduates. In March 2009, the government also took initiative to establish the Graduate Employability Management Scheme (GEMS) to equip unemployed graduates with commercially useful skills and experiences that would enhance their employment opportunities.

The high number of graduate unemployment has raised several questions to be investigated. In this article, the main question to be explored is whether the graduates from universities or other institutions are employable based on the current patterns of job demand via electronic advertisement. This question will be answered based on four criteria: the qualification, academic score, experience and specific soft skills. The major point to ponder is whether the current graduate characteristics are able to fulfill the requirement of employers in the job advertised.

\section{Methods and Materials}

The construction of this article was based on information gathered from job advertisement contents accessed via electronic databases at http://www.JobStreet.com.my. The JobStreet.com website is a renowned 'Internet Recruitment' in Asia-Pacific, operating since 1995 and offers a full range of interactive services to manage the recruitment process through a unique software application. There are six major categories of post offered in the website: manager, manager, senior executive, junior executive, fresh/entry level and non-executive. The distribution of posts can be searched in the website through 14 specializations or industry types and three major locations covering all states in Malaysia, ASEAN countries and the rest of world. As on 23 March 2011, there were 28,887 jobs offered in the website.

Since no filtration was provided in the web to select jobs offered according to candidate's academic eligibility and due to the large size of job advertisements, this research has limited it scope by choosing only ads that were based on the following criteria: (i) it must only come from five major specializations or industry sectors - that are construction industry, accounting/finance, engineering, computer/communication technology and the law, (ii) the industry must be operated and/or offers jobs in Malaysia, (iii) limited to advertisements issued from early January to end of March 2011 only, (iv) limited to jobs advertised for graduates only, and (v) limited to the post of manager and below. Based on these guidelines, 300 ads that represented industry specialization and its' subsectors were chosen to analyze using the quota sampling method.

The selection of job ads was done by constructing a simple checklist form which contained detailed information of industrial location, sector, specialization, company name, position, candidate qualifications, job types, academic achievements, skills needed, candidate attributes, and work experience requirements. These items extracted from the ads were transformed into a checklist for the purpose of analysis. The use of this method is 
following the recommendations by Berg (1989) who stated that the content analysis requires a systematic technique, specific and objective to draw conclusions from a text or explicit content. Through this method, qualitative information derived from the ads content were later transformed into quantitative data.

\section{Results and Discussion}

\subsection{Job Advertisement Profile}

From a total of 300 ads chosen, 60 ads were taken respectively from five industry sectors. For the construction industry, major ads sources were from business and management consultancy, manufacturing, engineering, technical consultancy, and hotel or tourism subsectors. For accounting/finance industry, most ads were from banking/finance, customer service center and retail or commercial subsectors. For the engineering industry, the ads were from biotechnology, pharmaceutical, chemical, fertilizers, electrical/electronics, defense/government and processing/production. For the law industry, the ads were from accounting/tax services, advertising/marketing, human resources management, business/management consultancy, legal, printing/ publishing and real estate/plantation. For computer/ICT industries, subsectors involved were art/design, engineering/technical consulting, human resources management/consulting, ICT/ software and hardware.

\subsection{Graduate Employability: Academic Eligibility}

Based on Table 1, it was found that 60.7 percent of the ads put requirements on first degree/professional degree as a prerequisite for job application among graduates. The findings indicated that job demand for graduates with degree alone was likely to be 37.4-56.7 percent much higher than others in diploma, certificate and Master/PhD. (see Table 1).

Table 1. Entry qualification for graduate post

\begin{tabular}{lcc}
\hline Qualifications & Frequency & Percent \\
\hline Certificates / Professional & 18 & 6.0 \\
Diploma High / Professional Diploma & 70 & 23.3 \\
First Degree or Professional Diploma & 18 & 6.0 \\
First Degree / Professional Degree & 182 & 60.7 \\
Master / PhD & 12 & 4.0 \\
\hline Total & 300 & 100 \\
\hline
\end{tabular}

By trends, the demand for first degree qualification was dominant in all industries observed which was 68 percent from law, 63.1 percent from computer/ICT, 43.8 percent from engineering, 42.6 percent from construction and 41.3 percent from accounting/finance. Some examples of the ads that stated first degree as a prerequisite were post of Assistant Manager (Business Development) at Destination Resorts and Hotels Sdn Bhd (DRH); Finance Manager at Jabil Sdn.Bhd (JSB), and Personal Assistant for Director at The Lion Group (TLG). Ads by DRH for example stressed that "candidate must possess at least a recognized degree in finance, management, accounting or economics" while JSB and TLG respectively stressed candidate "must possess at least a bachelor's degree or professional degree in finance/accountancy/banking" and "at least a bachelor's degree in finance/accounting or professional degree in ACCA/MACPA/CIMA".

High demand for degree qualifications did not mean graduates with certificate and diploma especially those from technical, vocational and professional institutions lagged behind. Generally it has specific job segments and demand in industries, especially for lower post. For example, more than 20 percent ads in all industries especially in finance/accounting industry demanded a minimum qualification of LCCI, MICPA, ICAA, ICAEW, ACCA, CIMA, MIA, CPA and other professional qualifications that was not degree for entry. These ads can be seen in various posts offered such as Finance Executive's by the CMC-I Resource Sdn. Ltd, Junior Accountant by Michael Page International, and Junior Auditor by POS Malaysia. In Engineering industry, post of Chemical Processing Technician and Specialized Technician also required qualified candidates with specific technical skills at diploma level, among them were from National Institute of Technical Education (NiTEC), graduate of Polytechnic Institute of Technical Education (PITP) and Institute of Technical Education (ITE).

\subsection{Graduate Employability: Academic Score}

An analysis of job demand based on academic achievement showed that 94 percent ads did not specify the requirement of Cumulative Grade Point Average (CGPA). This finding portrayed that although the majority of the employers were looking for graduates with degree, they tended to recruit candidates based on skills 
proficiency rather than academic excellence that was measured by CGPA. Based on 300 ads, only 6 percent stated CGPA requirement, mostly of "over 2.8" or "3.0 and above". Majority ads that stressed on CGPA were from accounting/finance, computer/ICT and engineering industries. These industries typically looked at the candidates with excellent academic achievement as it involved many aspects of work that required high attention on calculation, concentration, specific knowledge and expertise in the field. In sum, it can be concluded that academic achievement based on CGPA was not a major point in the ads, thus graduates have better chance to penetrate job market without worrying on the class or type of degree achieved. However, this did not mean the CGPA was set aside by the employers. Though it was not explicitly stated in the ads, this was seen as a strategy to increase candidate application during recruitment

\subsection{Graduate Employability: Work Experience}

Based on the information in Table 2, it was found that 40 percent ads analyzed required work experience for the post offered while 22 percent ads did not. The rest (12 percent) did not state any conditions whilst 26 percent stated that work experience was only an added advantage or given priority. Based on this finding, it was clear that less than two third of ads did not request any work experience, therefore only 22 percent jobs offered were likely to be filled by fresh graduates whereas more than 60 percent prefer graduates with working experiences. (see Table 2)

Table 2. Conditions of work experience in ads

\begin{tabular}{lcr}
\hline Work Experience & Frequency & Percent \\
\hline Compulsory / needed & 120 & 40 \\
Advantages / priority & 78 & 26 \\
Not needed & 66 & 22 \\
Not Stated & 36 & 12 \\
\hline Total & 300 & 100 \\
\hline
\end{tabular}

An analysis on ads contents showed that the highest number of industry that prescribed work experience as compulsory or most preferred was the construction industry, finance and engineering. A few examples of work experience assertion was shown in the ads by NRY Architects Sdn. Bhd. for the post of Resident Architect which stated 'at least 5 year(s) of working experience for building management or 8 years experiences in the related field is required for this position'; ads by UIG Architect Sdn Bhd. for the post of Architect that required 'minimum 1-2 years of relevant experience with exposure to high-rise development' and ads by Pembinaan Bintang Baru Sdn. Bhd. for the post of Admin Assistant Executive which stressed 'at least 3 year(s) of working experience in the related field'. Generally, major request for work experience was found in the classification of management and professional posts such as managers, executives, engineers, architects, designers and business planners. For employers that did not place the criteria of work experience, some offered specific training programs, internship, coaching, teamwork and on the job training (OJT) that provided a reflective work experience to fresh graduate recruited. For example, few companies like ON Semiconductor SCG Industries Sdn Bhd,, Iwatech Services \& Sales Sdn Bhd, and Hong Leong Bank (HLB) respectively offered 2-6 months onsite training, internship or coaching program for successful applicant. The request for working experiences among graduate was a big challenge since most of the fresh graduates were only equipped with very little job experience through industrial practicum or internship program during university studies.

\subsection{Graduate Employability: Soft Skills}

Table 3 lists five aspects of soft skills required by employers in the ads analyzed. Small percentage of ads did not specify the requirement of soft skills. The most required soft skills by the employers were communication or interpersonal skills (76 percent), followed by ICT/technical (68 percent), foreign language (64 percent), teamwork (36 percent) and personal qualities/attributes (34 percent). The finding of this research was quite similar with findings by Nurita et al. (2004) and Bunt et al. (2005) which arrayed communication and interpersonal skills as major soft skills required by employers during recruitment process. Generally, communication or interpersonal skill is an individual skill to properly interact with others within and outside organization. In the business domain, it generally refers to employee's ability to get along with colleagues and other people from different background while getting the job done. Thus good interpersonal skills are a prerequisite for many positions in organization. (see Table 3). 
Table 3. Soft skills required by employers $(\mathrm{n}=300)$

\begin{tabular}{lcrcc}
\hline Soft Skills & \multicolumn{2}{c}{ Yes } & \multicolumn{2}{c}{ Not Stated } \\
\cline { 2 - 5 } & Frequency & Percent & Frequency & Percent \\
\hline Communication / Interpersonal & 228 & 76 & 72 & 24 \\
ICT \& Technical & 198 & 66 & 102 & 34 \\
Foreign Language(s) & 192 & 64 & 108 & 36 \\
Teamwork & 108 & 36 & 192 & 64 \\
Personal Quality & 101 & 34 & 240 & 66 \\
\hline
\end{tabular}

Based on the analysis, 90 percent ads from computer/communications industry required graduate with good communication/interpersonal skills, while ads in other industry have less percentage. Few example, ads statements were: 'must possess good interpersonal skills', 'excellent communication skills,' 'able to communicate with all levels of employees', 'people friendly', 'able to liaise with consultants and construction team', and 'must be tactful when dealing with customers'. The ads by MU Technology Industries for the post of Business Solution Analyst for example requested graduate with 'strong communications skills with a demonstrable ability to interact and influence at all levels within the organization as well as with end users'.

Concerning foreign language skills, majority ads requested graduates who were able to speak and write fluently at least in one foreign language. Roughly, 60-76 percent ads in all five industries required languages proficiency mainly in English and Chinese. Most ads stressed that the 'candidates must be fluent or able to speak in Malay and Mandarin', 'candidates must be fluent with English and Bahasa Malaysia', 'excellent command of written and oral English, Bahasa Malaysia and/or Mandarin /Cantonese' and 'able to write reports in English'. Some examples were the post of Tax Consultant/Officers by T.K Lim Tax Services Sdn. Bhd. which required candidates who were 'able to communicate in Mandarin, English and Bahasa Malaysia' and ads by the Sunway Enterprise for the post of Branch Manager that needed 'excellent command in English, Malay and ability to converse in Mandarin'. Since most ads placed top priority on candidates' ability to speak and write in English, failure to communicate with a satisfactory level of confidence will affect graduate employability in recruitment. This becomes even more crucial since 11 percent ads requested graduates with the ability to speak in three languages, namely Malay, English and Mandarin. Therefore, graduate employability skill in foreign language was very important since many research demonstrated that most candidates were weak English.

For ICT/technical skills that are generally referred to technology and technical information including computer software/hardware and other specific technical capabilities, an analysis found that more than 87 percent ads from computer/ICT industry required graduates with computer/ICT expertise while 45-65 percent ads from other sectors requested the same. Among general types of ICT/technical skills required were the ability to use MsOffice suites, particularly MsWord, Excel and PowerPoint whereas technical skills required were different according to specific sectors. Some examples of technical skills requested were handling of operating system, middleware and database management system for the position of Technical Engineer, and knowledge in Java, Java 2 Platform Enterprise Edition (J2EE) and JavaServer Pages (JSP) for the post of Program Analyst. These can be seen in ads by The Regional AML CI Lead Sdn. Bhd and by Ambank Berhad where both Analyst Programmer posts required mandatory and conversant ICT and technical expertise, mainly in SQL 2005/2008, VB, NET/ASP.NET, Java Scripting, Web Development, MSShare Point, MySQL, Linux and LDAP e-Directory development, Novell IDM product, and Share Point design and development. High demand by employers for workers with ICT and other specific technical skills were in line with the increasing use of sophisticated technology that required more skilled and intelligent workers (Heldrich, 2004; Nur Atiqah et al., 2006). This required higher institutions to integrate curriculum that can prepare students with both technical and adaptive functional skills especially in ICT (Zubaidah and Rugayah, 2008; Nik Hairi et al., 2006).

With regards to teamwork, the study found that 36 percent ads highlighted the needs of teamwork skills. Despite the small percentage, request of teamwork skills existed in all industrial sectors such as 90 percent in the engineering industry and the law, and between 50 to 60 percent in other industries. By trends, most sectors needed candidates who were able to work as one team by indicating that 'candidate must be a good team player', 'possess positive teamwork spirits', 'able to liaise with construction team', 'able to work as a part of the team' and 'ability to work well both as an individual and in a team'. Such examples were ads by Command Alkon Sdn Bhd. for the post of Field Engineer which needed candidate 'with good analytical ability, high spirit team player, meticulous, and able to work independently'. 
In terms of personal qualities that generally refer to characteristics of good or positive attitude, discipline, hospitable, integrity, analytical, compliance of regulations, directives, responsible, independent and trust, the study found that these personal attributes were spelled out in roughly 34 percent ads. Out of this, 74 percent ads demanded at least two personal qualities from candidates while the rest demanded more than three attributes. Although majority of the employers did not overly stipulate the aspects of personal attributes in their ads, it was important for graduates to have positive personality because it was not only an assurance for getting the job but also to be successful in the career chosen. This is because the elements of personal attributes were weighed in the performance appraisal and can become a significant factor in promotion.

\section{Conclusion}

Based on the results, it can be concluded that graduates with degree qualification were more likely to be employed because of high demand. It was also found that an academic excellence based on CGPA was not the utmost factor for graduate employability. However, graduate employability became an issue since more than two third ads requested working experience. Another factor that may limit graduate employability was high demand of specific soft skills by employers, among which were graduates with high quality of communication/interpersonal skills, foreign language proficiency, ICT and technical abilities, high spirit of teamwork and specific personal attributes.

In general, employers' demand for communication or interpersonal skills was centered on the issues of graduate abilities to perform good communication skills either horizontally or vertically, within and outside organization. The employers also required graduates with good skills in reading, listening, responding, understanding, writing and making effective presentation. This finding was consistent with previous research worldwide which generally concluded that employers demonstrated a high agreement on soft skills related to communication, problem solving, ICT and technical skills, team work, motivation, independence and self-confidence (Winterbotham et al., 2001; Abd. Aziz Yusof, 2003; Ahmad et al., 2009). Of language skills, most ads placed top priority on candidates' ability to speak and write English, thus failure to communicate with a satisfactory level of confidence will also affect graduate employability in recruitment. Some ads requested graduates with the ability to speak in three languages, namely Malay, English and Mandarin. Although this request was against fair recruitment policy as it was a form of racial discrimination, this should seem fair as additional advantage and skills in various international languages were becoming more important in this era. Graduates were also required to demonstrate good ability of teamwork in addition to possessing excellent personal qualities as such skills in negotiation, problem solving, responsibility, self-sufficiency, learning, leadership and multitasking.

Graduate unemployment will continue to increase unless the HEI and graduates are prepared to sharpen the soft skills. For university, the most important thing to note is whether they are able to produce students with those kinds of employability skills required by employers. While all public universities in Malaysia is offering a mandatory non-curricular activities to guarantee graduate employability, the method of conducting activities and the evaluation must be more precise and reflect the job demand and changing economic environment. The Universiti Kebangsaan Malaysia (UKM) for example has approved more than 633 Learning Contract (LC) between March 2011 to April 2012 to cultivate soft skills for students in various activities such as social entrepreneurial, business, clubs, social work, society involvement, dinner, marketing, seminars and others. In general, students are able to gain eight learning outcomes (soft skills) from various activities. However, since LC does not totally focus on job requirement, the skills gained by students may be a mismatch for specific jobs, especially within private companies. Nevertheless, the conduct of LC must be viewed as an excellent step taken by public universities to provide students with soft skills.

To enhance students soft skills, it is suggested that all HEI especially public universities to work more closely with industries, professional bodies and society through establishment of Memorandum of Understanding (MoU) for the implementation of Specific Corporate Social Responsibilities (CSR), Course Development (CD), Learning Contract (LC) and another types of university-industry link cooperation involving internship, seminars, research, work placements, practicum, industrial practicum, student mobility and other enhancement programs. To make these efforts imperative, the strategy must be reinforced by law which enable compulsory requirement for industries or other bodies to engage with HEI. Some financial incentives like tax breaks or subsidies are important to implement the recognition of the cooperation as it helps to cover the cost of engagement. The related ministerial and HEI should also play an active role to make this strategy as one of the Key Performances Indicators (KPI) for the institutions.

Beside those strategies, another proactive steps that can be taken by HEI is by providing link with industries and professional bodies for development of academic courses in conjunction with employers' need. HEI and 
industries can also work closely through exchange program, among which by inviting employers to take part in certain lectures conducted at university or industry, providing placements to lecturers in industries to help them better understand the industry for teaching purposes, increasing alumni members among industries, using employers for verification of vocational courses, nominating external examiners from industries for academic exercise and other activities that can raise the profile of employers in a university and vice versa. Through this collaboration, it is hoped that the employers could observe and articulate graduate skills much better and be able to voice their views for improvement through the channel for future graduate employability.

\section{References}

Abd. Aziz Yusof. (2003). Komunikasi untuk Pengurus. Utusan Publications \& Distributors Sdn. Bhd.

Abdul Rahim M. Ali. (2000). Ilmu Pendidikan DPM. Siri Pengajian dan Pendidikan Utusan. Kuala Lumpur. Utusan Publications \& Distributors.

Ahmad Asrul Ibrahim, Azah Mohamed, \& Asraf Mohamed Moubark. (2009). Status kebolehpasaran graduan Kejuruteraan Elektrik, Elektronik dan Sistem, UKM. Kertas Seminar Pendidikan Kejuruteraan Kongres Pengajaran dan Alam Bina (PeKA '09). Bangi. Universiti Kebangsaan Malaysia.

Berg, B. L. (1989). Qualitative research methods for the social sciences (4th ed.). Needham Heights. California State University.

Bunt, K., McAndrew, F., \& Kuechel, A. (2005). Jobcentre Plus Employer (Market View)Survey 2004. Sheffield: DWP.

Devins, D., \& Hogarth, T. (2005). Employing the unemployed: Some case study evidence on the role and practice of employers. Urban Studies, 42(2), 245-256. http://dx.doi.org/10.1080/0042098042000316128

Kamal Khir. (2006). Training employable graduates: Innovation in training methodology. Paper presented at National Conference on Continuing Technical Education \& Training 2006, Challenges in Technical Education and Training; Enhancing Employability among Graduates 28-29 July 2006, The. Katerina Hotel, Batu Pahat Johor

Learning and Skills Council. (2003). National Employers Skills Survey 2003: MainReport. UK: LSC.

Mason, G., Williams, G., \& Crammer, S. (2006). Employability skills initiatives in Higher Education: What effects do they have on graduate labour market outcomes? London: National Institute of Economic and Social Research and Institute of Education.

Mohamad Sattar Rasul, Md Yusof Ismail, Napsiah Ismail, Rashid Rajuddin, \& Rose Amnah Abd. Rauf. (2009). Aspek kemahiran 'employability' yang dikehendaki majikan industri pembuatan masa kini. Jurnal Pendidikan Malaysia, 34(2), 67-79.

Mohd. Sobri Minai, \& Yusnidah Ibrahim. (1990). Pengangguran dan gunatenaga tak penuh: Apa kurangnya siswazah kita? Bagaimanakah cara untuk mengatasinya. Persidangan Kependudukan dan Orientasi Pembangunan Menjelang Abad Ke-21. Fakulti Sains Pembangunan, Universiti Kebangsaan Malaysia Kampus Sabah.

MOHE. (2009). Modul Pembangunan Kemahiran Insaniah (Soft Skills) untuk Institusi Pengajian Tinggi Malaysia. Putrajaya: Jabatan Pengurusan Institusi Pengajian Tinggi.

Newton, B., Hurstfield, J., Miller, L., Page, R., \& Akroyd, K. (2005). What employers look for when recruiting the unemployed and inactive: skills, characteristics and qualifications. Leeds: Department for Work and Pensions.

Nik Hairi Omar, Mohd Azul Mohamed Salleh, \& Norizan Abdul Razak. (2006). Penilaian kecekapan teknologi maklumat (TKM) dalam kalangan pelajar Sains Sosial. Jurnal Pendidikan, 63-77.

Nur Atiqah Abdullah, Ahmad Khairy, A.D., \& Nik Mutasim, N. A. R. (2006). Permintaan firma terhadap industri tenaga kerja Teknologi Maklumat dan Komunikasi di Malaysia. Jurnal Teknologi Maklumat \& Multimedia, 3, 71-87.

Nurita, Shaharudin, \& Ainon. (2004). Perceived employability skills of graduating students:Implications for SMEs.

Sherer, M., \& Eadie, R. (1987). Employability skills: Key to success. Thrust, 17(2), 16-17.

Singh, G. K.G., \& Singh, S. K. G. (2008). Malaysian graduates' employability skills. UniTAR e-Journal, 4(1), $15-45$. 
Suresh, R. (2006). $70 \%$ of grads from public institutions jobless. Retrieved from http://www.sun2surf.com/article.cfm?id=14660

Taylor, A. (2005). What employers look for: The skills debate and the fit with youth perception. Journal of Education and Work, 18(2), 201-218. http://dx.doi.org/10.1080/13639080500085984

Winterbotham, M., Adams, L., \& Kuechel, A. (2001). Evaluation of the work based learning for Adults Programme since April 2001: Qualitative interviews with ES Staff, Providers and Employers. Sheffield: DWP.

Yorke, M. (2008). Employability in higher education: What it is and what it is not. Higher Education Academy: ESECT.

Zubaidah Awang, \& Rugayah Mohamed. (2008). Imperative attributes for graduate employability in manufacturing firms: Issues for internationalising Malaysia's Curricula. In Dlm. Sarjit Kaur, Morshidi Sirat \& Norzaini Azman (Eds.), Globalisation and internationalisation of higher education in Malaysia. (p. 248). IPPTN. Pulau Pinang: Universiti Sains Malaysia. 